\title{
Lamivudine sensitivity - a case report
}

\author{
Leelavathy Budamakuntla ${ }^{*}$, Prabhakar Basappa ${ }^{2}$, Vidya Shankar ${ }^{2}$ Nirmala², Ravi Kumar ${ }^{1}$, Shwetha Suryanarayana ${ }^{1}$ \\ From 2nd International Science Symposium on HIV and Infectious Diseases (HIV SCIENCE 2014) \\ Chennai, India. 30 January - 1 February 2014
}

\section{Background}

Lamivudine is a dideoxy nucleoside analogue - NRTI, widely used in the treatment of HIV infection. It is a best tolerated drug with long term safety profile and most preferred in all regimens. Skin hypersensitivity reactions to lamivudine are rare and reported to be around $9 \%$.

\section{Case report}

A 29 year old HIV positive female was initiated on ART on 5/11/2012 with first line regimen, (TDF+3TC+NVP) as patient was anaemic. Patient came back with Nevirapine rash and ART was stopped on 20/12/12. Nevirapine was substituted with Efavirenz after rashes healed on $2 / 1 / 13$. Patient developed severe itching with rashes just after three doses and hence ART was stopped. After one month, she was counseled, hospitalized and was rechallenged with only $\mathrm{TDF}+3 \mathrm{TC}$; patient again developed severe itching with only one dose. Hence, patient was challenged with only lamivudine. With just one dose of lamivudine, patient developed hypersensitivity reaction within few hours with facial oedema, redness, tightness of skin with maculopapular rash and generalized blanchable erythema, giddiness, and hypotension and collapsed. She was resuscitated with dopamine, IV fluids and antihistamines.

\section{Conclusion}

Nucleoside reverse transcriptase inhibitors (NRTIs) such as lamivudine can cause skin rash in $1-10 \%$ of patients. Lamivudine related cutaneous side effects are probably under estimated. Lamivudine hitherto considered a safe drug can cause serious side effects in some patients as reported here. Hence, careful observation and timely

\footnotetext{
* Correspondence: drleelaskincare@rediffmail.com

'Department of Dermatology, Bowring \& Lady Curzon Hospital, Bangalore

Medical College\& Research Institute, Bangalore, Karnataka, India

Full list of author information is available at the end of the article
}

intervention is mandatory to avoid fatalities in those patients receiving NRTI based antiretroviral therapy.

\section{Authors' details}

${ }^{1}$ Department of Dermatology, Bowring \& Lady Curzon Hospital, Bangalore Medical College\& Research Institute, Bangalore, Karnataka, India. ${ }^{2}$ Department of Medicine, Centre of Excellence for ART, Bowring \& Lady Curzon Hospital, Bangalore Medical College \& Research Institute, Bangalore, Karnataka, India.

Published: 27 May 2014

doi:10.1186/1471-2334-14-S3-E39

Cite this article as: Budamakuntla et al:: Lamivudine sensitivity - a case

report. BMC Infectious Diseases 2014 14(Suppl 3):E39.

\section{Submit your next manuscript to BioMed Central and take full advantage of: \\ - Convenient online submission \\ - Thorough peer review \\ - No space constraints or color figure charges \\ - Immediate publication on acceptance \\ - Inclusion in PubMed, CAS, Scopus and Google Scholar \\ - Research which is freely available for redistribution

C Biomed Central

(c) 2014 Budamakuntla et al; licensee BioMed Central Ltd. This is an Open Access article distributed under the terms of the Creative Commons Attribution License (http://creativecommons.org/licenses/by/4.0), which permits unrestricted use, distribution, and reproduction in any medium, provided the original work is properly cited. The Creative Commons Public Domain Dedication waiver (http://creativecommons.org/publicdomain/zero/1.0/) applies to the data made available in this article, unless otherwise stated. 